\title{
Molecular investigation of mechanical strain-induced phenotypic plasticity in the ecologically important pharyngeal jaws of cichlid fish
}

\author{
By H. M. Gunter ${ }^{1,2}$ and A. Meyer ${ }^{1}$ \\ ${ }^{1}$ Lehrstuhl für Zoologie und Evolutionsbiologie, Department of Biology, University of Konstanz, Konstanz, Germany; \\ ${ }^{2}$ Zukunftskolleg, University of Konstanz, Konstanz, Germany
}

\begin{abstract}
Summary
Phenotypic plasticity in the form of alterations to teleost skeletons can result from a range of environmental factors, such as the hardness of the prey, particularly when exposure occurs early during development. Determining the molecular underpinnings of teleost skeletal plasticity is hampered by a limited understanding of the molecular basis of bone remod eling in derived teleost fish, whose bones are acellular, lack ing the cell type known to orchestrate bone remodeling in mammals. We are using a fitting molecular model for phenotypic plasticity research: the East African cichlid Astatoreochromis alluaudi, with the aim to shed light on the molecular basis of phenotypic plasticity and on the remodel ing of acellular bones. For this fish, sustained ingestion of a hard diet induces a 'molariform' lower pharyngeal jaw (LPJ), with molar like teeth set in an enlarged, relatively dense jaw, while a softer diet results in a smaller, finer 'papilliform' LPJ morphology, representing the 'ground state' for this species. Through comparing genome wide transcription in molari form and papilliform LPJs, our previous research has shed light on the molecular basis of phenotypic plasticity in the teleost skeleton and by extension, on acellular bone remodel ing. In this manuscript we construct a model for the molecu lar basis of mechanically induced skeletal plasticity in teleosts, which involves iterative cycles of strain and compen satory cellular proliferation. Furthermore, we propose a framework for testing the potential influence of phenotypic plasticity and genetic assimilation on adaptive radiations.
\end{abstract}

\section{Mechanically-mediated phenotypic plasticity in the teleost skeleton}

The myriad skeletal forms displayed by teleost fish is the product of their evolutionary past and ecological present, through interactions between both genetic and epigenetic factors that act in concert to orchestrate ontogeny. An inherent property of vertebrate skeletons is their ability to respond to mechanical strain, which results in a better match between the strength and size of skeletal elements, to the physical forces that act upon them. An idea first

Current address: H. M. Gunter, Ediburgh Genomics, University of Edinburgh, Edinburgh, UK. posited by Julius Wolff in 1892, the law of bone remodel ing, has been subsequently supported by a considerable amount of evidence, both empirical and theoretical in nat ure (Wolff, 1892; Chamay and Tschantz, 1972; Frost, 1990; Mullender and Huiskes, 1995; Vieira et al., 2013) but also see Pearson and Lieberman (2004). Numerous instances of phenotypic plasticity of the teleost skeleton, both adaptive and maladaptive, have been attributed to the action of mechanical strain. Maladaptive deformities known to cause economic losses in aquaculture include spinal bending (lordosis and kyphosis), which results from neuromuscular influences (Gorman and Breden, 2007) and excessive swimming activity (Kihara et al., 2002), and vari ous fusions and malformations associated with mechanical overload and accelerated growth (Witten et al., 2009). On the other hand, putatively adaptive characteristics such as directional mouth asymmetry (Van Dooren et al., 2010) and pharyngeal jaw robustness and tooth size and shape in cichlids (Muschick et al., 2011; Gunter et al., 2013) result from mechanical strain due to food ingestion. Addi tionally, water velocity and exercise, which also exert mechanical stress on the skeleton, influence overall body shape in fish such as salmon, trout (Pakkasmaa and Piironen, 2001) and pumpkinseed sunfish (Robinson and Wilson, 1996; Yavno and Fox, 2013), in addition to influ encing the rate of ossification in the skeleton (Pakkasmaa and Piironen, 2001; Grünbaum et al., 2012).

Despite the abounding evidence that mechanical strain remodels the teleost skeleton, similar to mammals, little is known of its cellular and molecular mechanisms (Witten and Huysseune, 2009; Fiaz et al., 2010). Specifically, funda mental cellular differences exist between the bones of neo teleosts and mammals neoteleosts lack osteocytes, the cell type that evidently co ordinates bone remodeling amongst tetrapods (Witten and Huysseune, 2009). Thus, through understanding the molecular basis of strain medi ated bone remodeling in higher teleosts we can gain insight into the basis of phenotypic plasticity that is of both adaptive and economic importance. Additionally our research provides vital information on the role of osteo cytes in bone development, as neoteleosts clearly achieve bone remodeling in the absence of this cell type, which is supposedly indispensible for efficient bone remodeling in mammals (Bonewald, 2011). 


\section{Remodeling cellular vs acellular bone}

Mammalian bones, far from being static or dead tissues, are peppered with osteocytes: living cells that are housed in cana liculi, microscopic fluid filled canals that perforate bone (Bonewald, 2011). At localised areas of bones that have been exposed to mechanical strain, fluid is forced through the cana liculi causing shear stress on the membranes of osteocytes inducing a molecular cascade that increases the proliferation of osteoblasts (Thompson et al., 2012). The increased activity of osteoblasts causes a local increase in bone deposition in the regions that receive the highest amount of strain (Robling et al., 2006), at the expense of regions that receive less strain where bone may be resorbed by osteoclasts. This localised deposition and resorption of bone through the combined activ ity of osteoblasts and osteoclasts leading to alterations in bone shape, is termed bone modeling. If the strain magnitude exceeds the bone's resistance, damage such as microcracks can occur inducing bone remodeling, a process that involves concurrent bone resorption and deposition in discrete bone regions through the co ordinated action of osteoclasts and osteoblasts (Currey, 2002; Dean and Shahar, 2012).

As molecular signals that are critical to bone modeling and remodeling originate from osteocytes and higher teleosts lack this cell type, they must use an alternative mechanism to sense mechanical strain and induce osteoblast and osteo clast proliferation (Dean and Shahar, 2012; Shahar and Dean, 2013). While it has been clear for some time that acel lular teleost bones respond to mechanical strain (Meyer, 1987; Huysseune et al., 1994; Day and McPhail, 1996; Heg renes, 2001; Kranenbarg et al., 2005), it was only recently recognised that this is in part due to remodeling rather than purely modeling (Currey and Shahar, 2013). Additionally, while it was previously considered that only osteocytes extend their cell membranes into bone, it was subsequently demonstrated that the bone lining osteoblasts can have cyto plasmic extensions that permeate deep into the bone (Sire and Meunier, 1994). This provides a putative mechanism for sensing associated changes in fluid flow and suggests that while neoteleosts specifically lack osteocytes, they may use alternative cell types and achieve similar remodeling out comes as species with cellular bones.

\section{Transcriptional basis of skeletal remodeling in a modern teleost}

In spite of the economic and evolutionary importance of skeletal plasticity in neoteleosts, little is known of its molecu lar basis. Our research has recently addressed this topic in the pharyngeal jaws of the cichlid fish, Astatoreochromis allu audi: a model for phenotypic plasticity research for the last 50 years (Greenwood, 1965; Hoogerhoud, 1986a,b,c; Huysse une et al., 1994; Huysseune, 1995; Smits, 1996; Smits et al. 1996; Gunter et al., 2013). Notably, this species displays two morph in the wild (Hoogerhoud, 1986a; Huysseune et al., 1994; Huysseune, 1995), a molariform morph with hypertro phied pharyngeal jaws with large, molar like teeth, adapted to crushing hard shelled molluses (Greenwood, 1965; Witte, 1981) and a papilliform morph with more slender LPJ better adapted to chewing softer food items such as insects (Meyer,
1989; Slootweg et al., 1994) (Fig. 1). These two morphs are largely the product of diet induced phenotypic plasticity, where the sustained ingestion of a hard diet (from $\sim 30 \mathrm{~mm}$ SL) induces a molariform LPJ, while a soft diet results in a papilliform LPJ (Greenwood, 1959, 1965; Hoogerhoud, 1986a,b; Smits, 1996; Smits et al., 1996) (Table 1). The molariform morph displays increased trabecular bone density (Huysseune et al., 1994) and progressively larger generations of replacement teeth (Huysseune, 1995), leading to the hypothesis that the molariform morph develops through increased mechanical strain on the jaws as a result of the dif ferent diets. Further support for this hypothesis came from finite element analysis of the LPJs of a neotropical cichlid, which demonstrated that the region receiving the highest mechanical strain during food intake was also the densest and bore the largest teeth (Hulsey et al., 2008).

While the morphological implications of diet induced LPJ plasticity have been well characterised, its molecular basis was only recently investigated. To achieve this objective, we conducted a transcriptome analysis of phenotypic plasticity in the $A$. alluaudi LPJ, comparing genome wide gene expres sion in molariform and papilliform LPJs (Gunter et al., 2013). Our investigation identified 187 differentially expressed transcripts, which shed light on teleost skeletal plasticity and by extension the molecular basis of acellular bone remodel ing. Here we have used these results to construct a model of the molecular basis of mechanically induced skeletal plastic
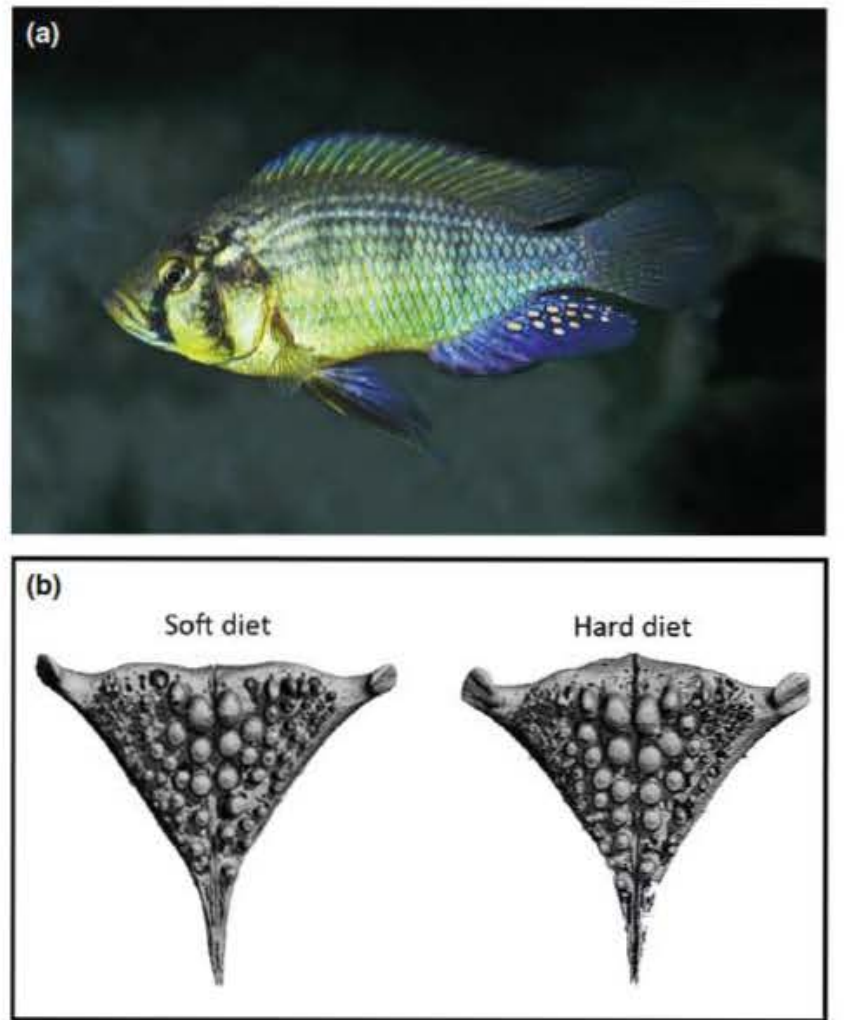

Fig. 1. Diet induced adaptive plasticity in the lower pharyngeal jaws (LPJ) of the cichlid Astatoreochromis alluaudi. (a) A. alluaudi mature male. (b) Ingestion of either hard shelled snails, or soft, pulverised snails induces the development of alternative LPJ morphs, character ised by differences in tooth size, jaw size and jaw shape 
Table 1

Mechano responsive pathways expressed in mammalian bones, compared to our analyses on the LPJ of a cichlid fish

\begin{tabular}{|c|c|c|}
\hline Gene Class & Mammalian & Cichlid \\
\hline AP 1 & $\begin{array}{l}\text { Mantila Roosa et al. (2011b) } \\
\text { Xing et al. (2005) }\end{array}$ & $\begin{array}{l}\text { Gunter et al. } \\
\text { (2013) }\end{array}$ \\
\hline Apoptosis & $\begin{array}{l}\text { Mantila Roosa et al. (2011b), } \\
\text { Xing et al. (2005) }\end{array}$ & $\begin{array}{l}\text { Gunter et al. } \\
(2013)\end{array}$ \\
\hline $\begin{array}{l}\text { Calcium } \\
\text { signalling }\end{array}$ & $\begin{array}{l}\text { Mantila Roosa et al. (2011b), } \\
\text { Xing et al. (2005) }\end{array}$ & Gunter et al. \\
\hline Cell cycle & Mantila Roosa et al. (2011b) & $\begin{array}{l}\text { Gunter et al. } \\
(2013)\end{array}$ \\
\hline Chemokine & $\begin{array}{l}\text { Mantila Roosa et al. (2011b), } \\
\text { Xing et al. (2005) }\end{array}$ & $\begin{array}{l}\text { Gunter et al. } \\
\text { (2013) }\end{array}$ \\
\hline Cytokine & $\begin{array}{l}\text { Mantila Roosa et al. (2011b), } \\
\text { Xing et al. (2005) }\end{array}$ & $\begin{array}{l}\text { Gunter et al. } \\
\text { (2013) }\end{array}$ \\
\hline Cytoskeleton & Xing et al. (2005) & $\begin{array}{l}\text { Gunter et al. } \\
(2013)\end{array}$ \\
\hline Growth factors & $\begin{array}{l}\text { Mantila Roosa et al. (2011b), } \\
\text { Xing et al. (2005) }\end{array}$ & \\
\hline $\begin{array}{l}\text { Heat shock } \\
\text { proteins }\end{array}$ & Xing et al. (2005) & $\begin{array}{l}\text { Gunter et al. } \\
\text { (2013) }\end{array}$ \\
\hline Ion Channel & Mantila Roosa et al. (2011b) & $\begin{array}{l}\text { Gunter et al. } \\
\text { (2013) }\end{array}$ \\
\hline Matrix & $\begin{array}{l}\text { Mantila Roosa et al. (2011b), } \\
\text { Xing et al. (2005) }\end{array}$ & Gunter et al. \\
\hline Muscle & $\begin{array}{l}\text { Mantila Roosa et al. (2011b), } \\
\text { Xing et al. (2005) }\end{array}$ & $\begin{array}{l}\text { Gunter et al. } \\
(2013)\end{array}$ \\
\hline Neurotransmitter & Mantila Roosa et al. (2011b) & \\
\hline $\begin{array}{l}\text { Signal } \\
\text { transduction }\end{array}$ & $\begin{array}{l}\text { Mantila Roosa et al. (2011b), } \\
\text { Xing et al. (2005) }\end{array}$ & $\begin{array}{l}\text { Gunter et al. } \\
\text { (2013) }\end{array}$ \\
\hline Solute carrier & $\begin{array}{l}\text { Mantila Roosa et al. (2011b), } \\
\text { Xing et al. (2005) }\end{array}$ & $\begin{array}{l}\text { Gunter et al. } \\
(2013)^{\mathrm{a}}\end{array}$ \\
\hline Tgf $\beta$ signalling & Mantila Roosa et al. (2011b) & $\begin{array}{l}\text { Gunter et al. } \\
(2013)^{\mathrm{b}}\end{array}$ \\
\hline $\begin{array}{l}\text { Wnt } / \beta \text { catenin } \\
\text { signalling }\end{array}$ & Mantila Roosa et al. (2011b) & \\
\hline
\end{tabular}

${ }^{\text {a }}$ Differential expression of solute carriers was detected in less strin gent RNA seq statistical analyses.

${ }^{b}$ Differential expression of $b m p 2$, a member of the Tgf $\beta$ family, was detected using qRT PCR but not RNA seq.

ity and to make predictions about the role of phenotypic plasticity in evolution.

\section{Transcription during remodeling of teleost acellular bones}

Importantly, our study has shed light on the molecular pro cesses that underlie mechanical strain induced remodeling of teleost acellular bones, which are strikingly similar to those that remodel mammalian cellular bones (Xing et al., 2005; Mantila Roosa et al., 2011a,b). For example molariform LPJs showed an increased expression of several immediate early genes (c fos, ier2) and calcium pathway genes (ryano dine and annexin). Overexpression of $\mathrm{c}$ fos may indicate an enhanced proliferation of osteoclasts, as this gene is a key osteoclast determinant in mammals (Grigoriadis et al., 1994). In concert with this, we observed the overexpression of genes involved with osteoblast proliferation and differentiation (osx and runx $2 b$ ), which in light of the putatively increased prolif eration of osteoclasts suggests that development of molari form LPJs involves active bone remodeling. Cross talk is likely to have occurred between osteoblast and osteoclast differentiation pathways as, for example, runx 2 and $\mathrm{c}$ fos functionally interact during mechanical strain enabling co ordinated activity of osteoblasts and osteoclasts (D'Alonzo et al., 2002). Moreover, we detected the upregulation of cx43, a gap junction gene that regulates communication between osteocytes and osteoblasts in mammalian bones ( $\mathrm{Su}$ et al., 1997; Taylor et al., 2007), demonstrating the importance of gap junction communication in the remodeling of acellular bones. It should be noted that $\mathrm{cx} 43$ is also associated with tooth development (About et al., 2002) and response to tooth damage (Mitsiadis and Rahiotis, 2004), so confirming its precise role requires further spatial investigations. Last, various lipid pathway genes were downregulated in molari form LPJs, suggesting that increased numbers of mesenchy mal cells may be recruited at a cost to adipose cells (Beresford et al., 1992) that fill the medullary cavities of tele ost bones (Witten and Huysseune, 2009).

Several genes involved in the immune response were signif icantly downregulated in molariform LPJs, as shown by our functional annotation analyses, which indicated the overrep resentation of terms such as immune response (7 of 27 genes), response to wounding (5 of 27) and inflammation (4 of 27). This observation is consistent with the proposal that the inflammatory response influences teleost skeletal deformi ties (Gil Martens, 2010) and with Vieira et al. (2013), who detected the expression of various immune related genes in the bones of gilthead sea bream in response to starvation stress. Moreover, human studies have demonstrated the altered expression of inflammatory genes in response to aero bic exercise (Bruunsgaard, 2005). As immune cell lineages such as macrophages and osteoclasts share a common pre cursor (hematopoietic stem cells), our observation suggests that molarifom LPJs may display a shift in stem cell differen tiation that favours osteoclasts over macrophages (Yin and $\mathrm{Li}, 2006)$. This may be of particular importance for the eruption of larger molariform teeth in the hard diet individu als, as the process of tooth eruption requires extensive bone remodeling and teeth are replaced approximately every month for this species (Huysseune, 1995). The proposed shift in hematopoietic stem cell differentiation may be driven in part by the overexpression of $\mathrm{c}$ fos, as mouse $\mathrm{c}$ fos knock outs display an overabundance of macrophages and a dra matic reduction in osteoclasts (Yang and Karsenty, 2002).

\section{A model for transcriptional basis of plasticity in the LPJ of a cichlid fish}

The pathways identified by our study have enabled the con struction of a model for the molecular basis of strain mediated remodeling of the LPJ of $A$. alluaudi (Fig. 2), which may be relevant to the remodeling of teleost bones more generally. We predict that the genes identified by our study form an inte grated network that both responds to mechanical strain and subsequently induces a downstream morphological response (Gunter et al., 2013; Young, 2013). For example, runx2 is known to induce expression of collagen genes (Zheng et al., 2003) and $c$ fos is known to induce periostin, which is involved in bone and tooth repair (Kashima et al., 2009). Additionally, as was noted earlier, runx 2 and $c$ fos functionally interact in 

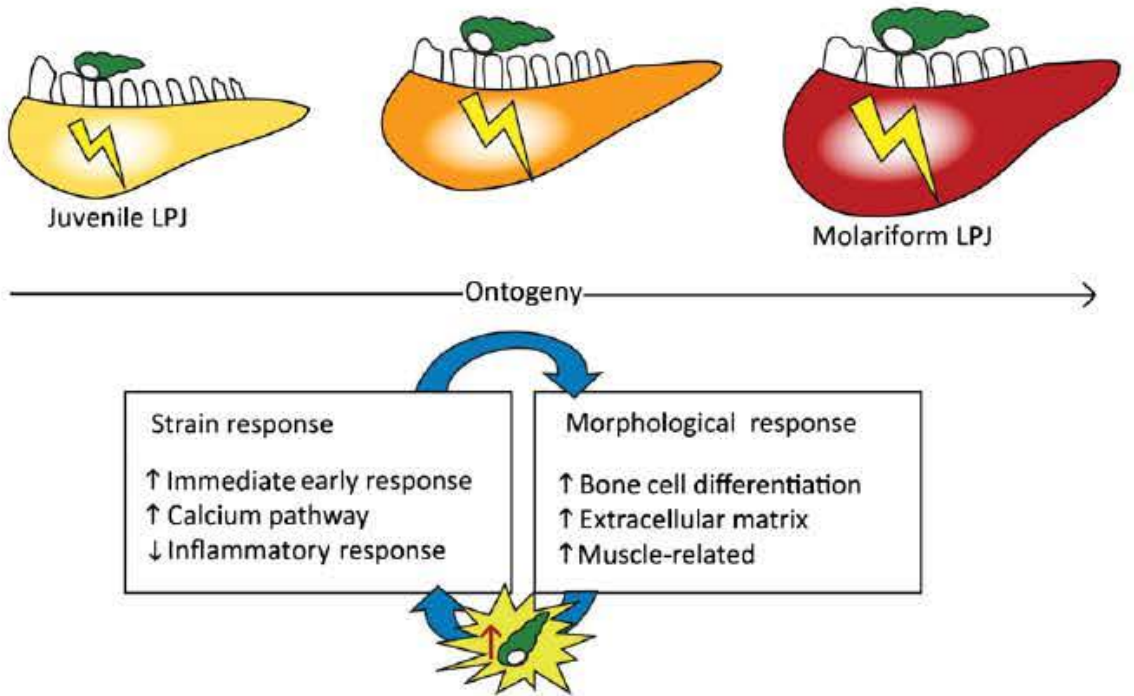

Fig. 2. Model of the transcriptional basis of phenotypic plasticity in the LPJ of a cichlid. The act of breaking hard shelled snails between the upper and lower pharyngeal jaws invokes a multi stage transcriptional response that leads to gradual increases in jaw density and tooth size over time. Mechanical strain induces an immediate response, which secondarily induces morphological pathways that are predicted to alter the size and shape of the LPJ. Through offering our fish progressively larger snails throughout the experimental period, strain responses of ever increasing magnitude were induced, leading to exaggerated expression of morphological pathways, leading the LPJ to become progres sively larger over time to resist the increased forces exerted by the hard shelled snails.

response to mechanical strain (D'Alonzo et al., 2002). Wolff's law predicts that compensatory growth in response to the application of mechanical strain (from snail crushing) would ultimately attenuate the strain induced transcriptional response. However, we consider that this growth only affords the fish to crush progressively harder prey items inducing a strain response of ever higher magnitude, bounded only by the maximal hardness of the ingested food items and the architec tonic constraints that the other cranial bones impose on LPJ growth (Smits et al., 1996).

There is an evolutionary arms race going on between the hardness of the snail shells and the cracking force that the fish can muster. This results in broken teeth in quite a few indi vidual cichlid fish that we have examined (A. Meyer, pers. obs.). Indeed, our experimental design took this into account, by offering snails of ever increasing size throughout the 18 month treatment period. Our data support the hypothesis that the molariform morph develops through the iterative action of mechanical strain cycles on the pharyngeal jaw apparatus during growth of this and other species of cichlids, including fish in the neotropical Midas cichlid species flock (Amphilophus cf. citrinellus) in which we have done similar experiments (Meyer, 1990, 1993; Muschick et al., 2011). The entire pharyngeal mill performs as a single functional unit and not only the bones and teeth of the lower pharyngeal jaw (the fifth ceratobranchial bones) are affected, but also the upper pharyngeal jaw (formed by the infrapharyngobranchi als) and the apophysis on the ventral side of the neurocrani um (the functional joint against which the upper pharygeal jaw abuts) are enlarged in molariform fish compared to papil liform fish. This is consistent with previous observations on the A. alluaudi LPJ, which showed that progressively larger generations of teeth developed in molariform jaws (Huysse une, 1995) and that plasticity in LPJ size cannot be induced in aquarium raised adult $A$. alluaudi, which do not grow dur ing the treatment period (Smits, 1996).

\section{Role of phenotypic plasticity in teleost evolution}

In addition to providing insight into the molecular basis of acellular bone remodeling, our study has provided a basis upon which to test the role of phenotypic plasticity in the evolution of East African cichlid fishes, a lineage that has undergone rapid and explosive speciation (Meyer et al., 1990; Salzburger et al., 2005; Elmer et al., 2009). Due to the rapid ity of their speciation and limited genetic variability between species (Meyer et al., 1990; Elmer et al., 2009), it has been hypothesised that phenotypic plasticity and subsequent genetic assimilation has played a key role in cichlid evolution (Meyer, 1987, 1993; Wimberger, 1994; Stauffer and Gray, 2004). Namely, a hypothetical 'plastic' ancestor colonized the lakes of East Africa rapidly filling diverse trophic niches through developing alternate morphologies that facilitated efficient niche exploitation. Secondarily, these initially plastic phenotypes are thought to have become genetically fixed through the process of genetic assimilation. Indeed, A. alluau di belongs to a relatively basal lineage amongst cichlids (Salz burger et al., 2005) and experiments on other cichlid species suggest that basal lineages harbour plasticity for traits that are fixed in more derived lineages (Meyer, 1987, 1990; Mus chick et al., 2011). Our future investigations will test the hypothesis that genetic assimilation contributed to cichlid evolution, through investigating the evolution of regulatory sequences from the 'plasticity genes' identified by our study specifically focusing on the so called shear stress responsive elements (SSREs). We postulate that derived lineages from the lacustrine adaptive radiations will display a reduced degree of plasticity in response to a mechanically stimulating 
diet, matched by a reduction in SSREs in the promoter regions of the 'plasticity genes'. Our planned investigations will utilise a mechanistic knowledge of the molecular basis of acellular bone remodeling to test the role of adaptive pheno typic plasticity and subsequent genetic assimilation in a rap idly evolving lineage.

\section{Summary}

We are entering an exciting time, where new methods such as next generation DNA sequencing allow us to gain an under standing of the molecular basis of phenotypic plasticity in neoteleost acellular bones, which has been long assumed to occur through different mechanisms than the remodeling of cellular bones (Moss, 1962). Two recently established medaka reporter lines enable the in vivo visualisation of osteoblasts (Renn and Winkler, 2009) and osteoclasts (To et al., 2012), which offers the possibility to determine the cellular and molecular bases of altered bone remodeling in response to changes in mechanical environments (Wagner et al., 2003) and nutritional status (Vieira et al., 2013). Our research dem onstrates an unprecedented level of similarity between the molecular pathways involved in the remodeling of neoteleost acellular bones and mammalian cellular bones. We identified a multitude of molecular pathways that are sure to instruct future research on the ecologically and economically impor tant topic of acellular bone remodeling.

\section{Acknowledgements}

We wish to acknowledge funding obtained for this research from the Deutsche Forschungsgemeinschaft (DFG) and the Zukunftskolleg at the University of Konstanz. Additionally we gratefully acknowledge Christian Sturmbauer and Ger hard Skofitsch for providing microCT scans of $A$. alluaudi jaws. Lastly, we thank Ralf Schneider for helpful comments on this manuscript, as well as Shaohua Fan, Fan Xiong, Paolo Franchini and Carmelo Fruciano, who assisted with the research described in this manuscript.

\section{References}

About, I.; Proust, J. P.; Raffo, S.; Mitsiadis, T. A.; Franquin, J. C., 2002: In vivo and in vitro expression of connexin 43 in human teeth. Connect. Tissue Res. 43, 232237.

Beresford, J.; Bennett, J.; Devlin, C.; Leboy, P.; Owen, M., 1992: Evidence for an inverse relationship between the differentiation of adipocytic and osteogenic cells in rat marrow stromal cell cul tures. J. Cell Sci. 102, 341351.

Bonewald, L. F., 2011: The amazing osteocyte. J. Bone Miner. Res. 26, 229238.

Bruunsgaard, H., 2005: Physical activity and modulation of systemic low level inflammation. J. Leuk. Biol. 78, 819835.

Chamay, A.; Tschantz, P., 1972: Mechanical influences in bone remodel ing. Experimental research on Wolff's law. J. Biomech. 5, 173180.

Currey, J. D., 2002: Bones: structure and mechanics. Princeton Uni versity Press, Princeton, 15 pp., 337.

Currey, J.; Shahar, R., 2013: Cavities in the compact bone in tetra pods and fish and their effect on mechanical properties. J. Struct. Biol. 183, 107122.

D’Alonzo, R. C.; Selvamurugan, N.; Karsenty, G.; Partridge, N. C. 2002: Physical interaction of the activator protein 1 factors c Fos and c Jun with Cbfal for collagenase 3 promoter activa tion. J. Biol. Chem. 277, 816822.

Day, T.; McPhail, J. D., 1996: The effect of behavioural and mor phological plasticity on foraging efficiency in the threespine stickleback (Gasterosteus sp.). Oecologia 108, 380388.

Dean, M.; Shahar, R., 2012: The structure, mechanics relationship and the response to load of the acellular bone of neoteleost fish: a review. J. Appl. Ichthyol. 28, 320329.

Elmer, K. R.; Reggio, C.; Wirth, T.; Verheyen, E.; Salzburger, W.; Meyer, A., 2009: Pleistocene desiccation in East Africa bottlenecked but did not extirpate the adaptive radiation of Lake Victoria haplochromine cichlid fishes. Proc. Natl. Acad. Sci. USA 106, 1340413409.

Fiaz, A. W.; van Leeuwen, J. L.; Kranenbarg, S., 2010: Phenotypic plasticity and mechano transduction in the teleost skeleton. J. Appl. Ichthyol. 26, 289293.

Frost, H., 1990: Skeletal structural adaptations to mechanical usage (SATMU): 1. Redefining Wolff's law: the bone modeling prob lem. Anat. Rec. 226, 403413.

Gil Martens, L., 2010: Inflammation as a potential risk factor for spinal deformities in farmed Atlantic salmon (Salmo salar L.). J. Appl. Ichthyol. 26, 350354.

Gorman, K. F.; Breden, F., 2007: Teleosts as models for human vertebral stability and deformity. Comp. Biochem. Physiol. C 145, 2838.

Greenwood, P., 1959: The monotypic genera of cichlid fishes in Lake Victoria, Part II. Bull. Br. Mus. Nat. Hist. Zool. 7, 163177.

Greenwood, P. H., 1965: Environmental effects on the pharyngeal mill of a cichlid fish, Astatoreochromis alluaudi, and their taxo nomic implications. J. Proc. Linn. Soc. 176, 110.

Grigoriadis, A. E.; Wang, Z. Q.; Cecchini, M. G.; Hofstetter, W.; Felix, R.; Fleisch, H. A.; Wagner, E. F., 1994: c Fos a key reg ulator of osteoclast macrophage lineage determination and bone remodeling. Science 266, 443448.

Grunbaum, T.; Cloutier, R.; Vincent, B., 2012: Dynamic skeletogen esis in fishes: Insight of exercise training on developmental plas ticity. Dev. Dyn. 241, 15071524.

Gunter, H. M.; Fan, S.; Xiong, F.; Franchini, P.; Fruciano, C.; Meyer, A., 2013: Shaping development through mechanical strain: the transcriptional basis of diet dependent phenotypic plasticity in a cichlid fish. Mol. Ecol. 22, 45164531.

Hegrenes, S., 2001: Diet induced phenotypic plasticity of feeding morphology in the orangespotted sunfish, Lepomis humilis. Ecol. Freshw. Fish 10, 3542.

Hoogerhoud, R. J. C., 1986a: Taxonomic and ecological aspects of morphological plasticity in molluscivorous haplochromines (Pisces, Cichlidae). Ann. Mus. Roy. Afr. Centr. Sc. Zool. 251, 131134.

Hoogerhoud, R. J. C., 1986b: Ecological morphology of some cichlid fishes. PhD thesis, Leiden University, Leiden.

Hoogerhoud, R. J. C., 1986c: The adverse effects of shell ingestion for molluscivorous cichlids, a constructional morphological approach. Neth. J. Zool. 37, 277300.

Hulsey, C. D.; Roberts, R. J.; Lin, A. S. P.; Guldberg, R.; Streel man, J. T., 2008: Convergence in a mechanically complex phe notype: detecting structural adaptations for crushing in cichlid fish. Evolution 62, 15871599.

Huysseune, A., 1995: Phenotypic plasticity in the lower pharyngeal jaw dentition of Astatoreochromis alluaudi (Teleostei, Cichlidae). Arch. Oral Biol. 40, 10051014.

Huysseune, A.; Sire, J. Y.; Meunier, F. J., 1994: Comparative study of lower pharyngeal jaw structure in 2 phenotypes of Astatore ochromis alluaudi (Teleostei, Cichlidae). J. Morphol. 221, 2543.

Kashima, T. G.; Nishiyama, T.; Shimazu, K.; Shimazaki, M.; Kii, I.; Grigoriadis, A. E.; Fukayama, M.; Kudo, A., 2009: Periostin, a novel marker of intramembranous ossification, is expressed in fibrous dysplasia and in c Fos overexpressing bone lesions. Hum. Pathol. 40, 226237.

Kihara, M.; Ogata, S.; Kawano, N.; Kubota, I.; Yamaguchi, R., 2002: Lordosis induction in juvenile red sea bream, Pagrus major, by high swimming activity. Aquaculture 212, 149158.

Kranenbarg, S.; van Cleynenbreugel, T.; Schipper, H.; van Leeuwen, J., 2005: Adaptive bone formation in acellular vertebrae of sea bass (Dicentrarchus labrax L.). J. Exp. Biol. 208, 34933502. 
Mantila Roosa, S. M.; Liu, Y.; Turner, C. H., 2011a: Alternative splicing in bone following mechanical loading. Bone 48, 543551.

Mantila Roosa, S. M.; Liu, Y. L.; Turner, C. H., 2011b: Gene expression patterns in bone following mechanical loading. J. Bone Miner. Res. 26, 100112.

Meyer, A., 1987: Phenotypic plasticity and heterochrony in Cichlaso ma managuense (Pisces, Cichlidae) and their implications for speciation in cichlid fishes. Evolution 41, 13571369.

Meyer, A., 1989: Cost of morphological specialization feeding per formance of the 2 morphs in the trophically polymorphic cichlid fish, Cichlasoma citrinellum. Oecologia 80, 431436.

Meyer, A., 1990: Ecological and evolutionary consequences of the trophic polymorphism in Cichlasoma citrinellum (Pisces: Cichli dae). Biol. J. Linn. Soc. 39, 279299.

Meyer, A., 1993: Trophic polymorphisms in cichlid fish: do they rep resent intermediate steps during sympatric speciation and explain their rapid adaptive radiation? In: New Trends in Ich thyology. J. H. Schroder; J. Bauer and M. Schartl (Eds). Black well Scientific Publications, Oxford. pp. 257266

Meyer, A.; Kocher, T. D.; Basasibwaki, P.; Wilson, A. C., 1990: Monophyletic origin of Lake Victoria cichlid fishes suggested by mitochondrial DNA sequences. Nature 347, 550553.

Mitsiadis, T. A.; Rahiotis, C., 2004: Parallels between tooth develop ment and repair: conserved molecular mechanisms following carious and dental injury. J. Dent. Res. 83, 896902.

Moss, M. L., 1962: Studies of acellular bone of teleost fish. II. Response to fracture under normal and acalcemic conditions. Acta Anat. 48, 4660.

Mullender, M.; Huiskes, R., 1995: Proposal for the regulatory mech anism of Wolff's law. J. Orthop. Res. 13, 503512.

Muschick, M.; Barluenga, M.; Salzburger, W.; Meyer, A., 2011: Adap tive phenotypic plasticity in the Midas cichlid fish pharyngeal jaw and its relevance in adaptive radiation. BMC Evol. Biol. 11, 116.

Pakkasmaa, S.; Piironen, J., 2001: Water velocity shapes juvenile sal monids. Evol. Ecol. 14, 721730.

Pearson, O. M.; Lieberman, D. E., 2004: The aging of Wolff's "Law": ontogeny and responses to mechanical loading in corti cal bone. Am. J. Phys. Anthropol. 125, 6399.

Renn, J.; Winkler, C., 2009: Osterix mCherry transgenic medaka for in vivo imaging of bone formation. Dev. Dyn. 238, 241248

Robinson, B. W.; Wilson, D. S., 1996: Genetic variation and pheno typic plasticity in a trophically polymorphic population of pump kinseed sunfish (Lepomis gibbosus). Evol. Ecol. 10, 631652.

Robling, A. G.; Castillo, A. B.; Turner, C. H., 2006: Biomechanical and molecular regulation of bone remodeling. Annu. Rev. Bio med. Eng. 8, 455498.

Salzburger, W.; Mack, T.; Verheyen, E.; Meyer, A., 2005: Out of Tanganyika: genesis, explosive speciation, key innovations and phylogeography of the haplochromine cichlid fishes. BMC Evol. Biol. 5, 17.

Shahar, R.; Dean, M. N., 2013: The enigmas of bone without osteo cytes. BoneKEy. Rep. 2, 343.

Sire, J. T. Meunier, F. J., 1994: The canaliculi of Williamson in holostean bone (Osteichthyes, Actinopterygii): a structural and ultrastructural study. Acta. Zool. 75, 235247.

Slootweg, R.; Malek, E. A.; Mccullough, F. S., 1994: The biological control of snail intermediate hosts of schistosomiasis by fish. Rev. Fish Biol. Fisher. 4, 6790.

Smits, J. D., 1996: Trophic flexibility through spatial reallocation of anatomical structures in the cichlid fish Astatoreochromis alluau di. $\mathrm{PhD}$ thesis, University of Leiden, Leiden.

Smits, J. D.; Witte, F.; VanVeen, F. G., 1996: Functional changes in the anatomy of the pharyngeal jaw apparatus of Astatoreochr omis alluaudi (Pisces, Cichlidae), and their effects on adjacent structures. Biol. J. Linn. Soc. 59, 389409.

Stauffer, J. R.; Gray, E. V., 2004: Phenotypic plasticity: its role in trophic radiation and explosive speciation in cichlids (Teleostei: Cichlidae). Anim. Biol. 54, 137158.

Su, M.; Borke, J. L.; Donahue, H. J.; Li, Z.; Warshawsky, N. M.; Russell, C. M.; Lewis, J. E., 1997: Expression of connexin 43 in rat mandibular bone and periodontal ligament (PDL) cells dur ing experimental tooth movement. J. Dent. Res. 76, 13571366.

Taylor, A. F.; Saunders, M. M.; Shingle, D. L.; Cimbala, J. M.; Zhou, Z.; Donahue, H. J., 2007: Mechanically stimulated osteo cytes regulate osteoblastic activity via gap junctions. Am. J. Physiol. Cell Physiol. 292, C545 C552.

Thompson, W. R.; Rubin, C. T.; Rubin, J., 2012: Mechanical regula tion of signaling pathways in bone. Gene 503, 179193.

To, T. T.; Witten, P. E.; Renn, J.; Bhattacharya, D.; Huysseune, A.; Winkler, C., 2012: Rankl induced osteoclastogenesis leads to loss of mineralization in a medaka osteoporosis model. Develop ment 139, 141150.

Van Dooren, T. J. M.; Van Goor, H. A.; Van Putten, M., 2010: Handedness and asymmetry in scale eating cichlids: antisymme tries of different strength. Evolution 64, 21592165.

Vieira, F. A.; Thorne, M.; Stueber, K.; Darias, M.; Reinhardt, R.; Clark, M.; Gisbert, E.; Power, D., 2013: Comparative analysis of a teleost skeleton transcriptome provides insight into its regu lation. Gen. Comp. Endocrinol. 191, 4558.

Wagner, T.; Renn, J.; Riemensperger, T.; Volff, J. N.; Koster, R.; Goerlich, R.; Schartl, M.; Winkler, C., 2003: The teleost fish medaka (Oryzias latipes) as genetic model to study gravity depen dent bone homeostasis in vivo. Adv. Space Res. 32, 14591465.

Wimberger, P. H., 1994: Trophic polymorphisms, plasticity and spe ciation in vertebrates. In: Theory and application of fish feeding ecology. Bell Baruch Library in Marine Science. D. J. Stouder, K. L. Fresh and R. J. Feller (Eds), University of South Carolina Press, Columbia, SC, pp. 1943.

Witte, F., 1981: Initial results of the ecological survey of the haplo chromine cichlid fishes from the Mwanza Gulf of Lake Victoria (Tanzania) breeding patterns, trophic and species distribution with recommendations for commercial trawl fishery. Neth. J. Zool. 31, 175202.

Witten, P. E.; Huysseune, A., 2009: A comparative view on mecha nisms and functions of skeletal remodelling in teleost fish, with special emphasis on osteoclasts and their function. Biol. Rev. 84, 315346.

Witten, P. E.; Gil Martens, L.; Huysseune, A.; Takle, H.; Hjelde, K., 2009: Towards a classification and an understanding of develop mental relationships of vertebral body malformations in Atlantic salmon (Salmo salar L.). Aquaculture 295, 614.

Wolff, J., 1892: 1986 Das gesetz der transformation der Knochen. Translated as: The law of bone remodelling. Springer Verlag, Berlin, pp. 2374

Xing, W.; Baylink, D.; Kesavan, C.; Hu, Y.; Kapoor, S.; Chadwick, R. B.; Mohan, S., 2005: Global gene expression analysis in the bones reveals involvement of several novel genes and pathways in mediating an anabolic response of mechanical loading in mice. J. Cell. Biochem. 96, 10491060.

Yang, X.; Karsenty, G., 2002: Transcription factors in bone: develop mental and pathological aspects. Trends Mol. Med. 8, 340345.

Yavno, S.; Fox, M., 2013: Morphological change and phenotypic plas ticity in native and non native pumpkinseed sunfish in response to sustained water velocities. J. Evol. Biol. 26, 23832395.

Yin, T.; Li, L., 2006: The stem cell niches in bone. J. Clin. Invest. 116, 11951201.

Young, R. L., 2013: Linking conceptual mechanisms and transcrip tomic evidence of plasticity driven diversification. Mol. Ecol. 22, 43634365 .

Zheng, Q.; Zhou, G.; Morello, R.; Chen, Y.; Garcia Rojas, X.; Lee, B., 2003: Type $\mathrm{X}$ collagen gene regulation by Runx2 contributes directly to its hypertrophic chondrocyte specific expression in vivo. J. Cell Biol. 162, 833842.

Author's address: Helen M. Gunter, Department of Biology, Univer sity of Konstanz, Universitatstrasse 10, D 78457 Konstanz, Germany and Edinburgh Genomics, Ashworth Laboratories, University of Edinburgh, West Mains Road, Edinburgh, EH9 3JT, UK E mail: Helen.gunter@uni konstanz.de 